\title{
Microwave Assisted Synthesis of Six Member Ring Azaheterocycles and Their Antimycobacterial and Anticancer Evaluation
}

\author{
CRISTINA AL MATARNEH', CATALINA-IONICA CIOBANU ${ }^{2}$, \\ VIOLETA MANGALAGIU ${ }^{3}$, GHEORGHITA ZBANCIOC ${ }^{*}$, RAMONA DANAC ${ }^{*}$ \\ ${ }^{1}$ Chemistry Department, Faculty of Chemistry, Alexandru Ioan Cuza University of Iasi, 11 Carol I Blvd., 700506, Iasi, \\ Romania \\ ${ }^{2}$ Research Department, Faculty of Chemistry, Alexandru Ioan Cuza University of Iasi, 11 Carol I Blvd., 700506, Iasi, \\ Romania \\ ${ }^{3}$ Institute of Interdisciplinary Research- CERNESIM Centre, Alexandru Ioan Cuza University of Iasi, 11 Carol I Blvd., \\ 700506, Iasi, Romania
}

\begin{abstract}
We report herein a comparative study concerning the influence of microwave (MW) irradiation comparative with conventional thermal heating (TH) in the reaction of six member ring azaheterocycles (derived from phenanthroline, quinoline, isoquinoline and phthalazine) with ethyl cyanoformate, and their anticancer and antimycobacterial activity. Under MW irradiation the reactions have some undeniable advantages: the reaction times decrease dramatically (from hours to minutes), the yields are higher, the reactions became selective in some cases (4,7-phenanthrolinium and phthalazinium ylides). The decreasing of reaction time+ from hours to minutes corroborated with the fact that in majority of cases the yield are higher and the selectivity is better, allow us to say that these reactions could be considered as eco-friendly. As far for biological activity, three of the compounds exhibited a significant antitumor activity against some cancer cell lines including prostate cancer, leukemia, renal cancer, lung cancer and breast cancer. The best potency in terms of growth inhibition of tumor cells ( 45\%) was shown by compound 4 a against renal cancer A498 and ovarian cancer SK-OV-3 cells. The tested compounds have not shown any antimycobacterial activity against Mycobacterium tuberculosis.
\end{abstract}

Keywords: microwave irradiation; anticancer; antimycobacterial; eco-friendly.

\section{Introduction}

The microwave technology has been developed dynamically in recent years, which is manifested in new professional models of microwave reactors appearing on the market. Microwave technology is used in various applications, above all synthesis of organic chemistry, synthesis of nanomaterials, or the broadly understood materials processing [1-2]. MW assisted reaction has become a successful tool in medicinal and organic chemistry, having some undeniable advantages: shorter reaction times and milder conditions, generating less side products, using small amounts or no organic solvents (being eco-friendly reactions) and, in some cases, have higher yields comparative with conventional thermal heating (TH) [1-15].

On the other hand, six member ring azaheterocycles (especially phenanthroline, quinoline, isoquinoline and phthalazine derivatives) are multitarget pharmacophore with a large variety of biological activities such as antibacterial, antifungal, antitubercular, anticancer, antiplasmodial, antimalarial, anti-inflammatory, etc. [11, 16-25].

\footnotetext{
*email: gheorghita.zbancioc@uaic.ro;rdanac@uaic.ro
} 
Recently, our group reported the synthesis of several classes of six member ring azaheterocycles derived from phenanthroline, quinoline, isoquinoline and phthalazine, using conventional thermal heating conditions [26]. Being compounds with completely new cores, with a certain biological potential, and in continuation of our concern in the field of MW assisted reaction in medicinal and organic chemistry [5-13, 27-31], we decided to develop an efficient and general method for preparation of our azaheterocycles derivatives using MW irradiation and, to evaluate their anticancer and antimycobacterial activity.

\section{Materials and methods \\ General procedure}

All the reagents and solvents were purchased from commercial sources (Sigma Aldrich and Merck) and used without further purification. Melting points were recorded on an Electrothermal MEL-TEMP (Barnstead International, Dubuque, Iowa, USA) apparatus in open capillary tubes and are uncorrected. Analytical thin-layer chromatography was performed with commercial silica gel plates 60 F254 (Merck Darmstadt, Germany) and visualized with UV light. The NMR spectra were recorded on a (Bruker Vienna, Austria) Avance III $500 \mathrm{MHz}$ spectrometer operating at $500 \mathrm{MHz}$ for ${ }^{1} \mathrm{H}$ and 125 $\mathrm{MHz}$ for ${ }^{13} \mathrm{C}$. Infrared (IR) data were recorded as films on potassium bromide (KBr) pellets on a FT-IR (Shimadzu Kyoto, Japan) Prestige 8400s spectrophotometer. For the microwave irradiation we used a monomode reactor Monowave 300 (Anton Paar Graz, Austria). This reactor can reach up to $300^{\circ} \mathrm{C}$ and controls the temperature via a built-in IR sensor. Some additional specifications of Monowave 300: microwave power $850 \mathrm{~W}$, operation limits at $300^{\circ} \mathrm{C}$ and 30 bars, reaction vial Borosilicat, operation volume between $0.5-20 \mathrm{~mL}$, pressure control by hydraulic system, agitation with an integrated magnetic stirrer (0 to $1200 \mathrm{rpm}$ ) and cooling with compressed air.

\section{General Procedure for Synthesis of Azaheterocycles 2, 4, 6, 7, 9, 14, 18 and 19 under Conventional TH Conditions and MW Irradiation}

The MW irradiation setup procedure is as follow: the mixture of reagents (the corresponding cycloimmonium salt $(1 \mathrm{mmol}, 1$ equiv.) and ethyl cyanoformate $(1.1 \mathrm{mmol}, 1.1$ equiv. $)$ in $10 \mathrm{~mL}$ chloroform)) was placed into the reaction vessel and exposed to irradiation for $10 \mathrm{~min}$. Using MW irradiation, the best results were obtained using a "temperature control" method. The "temperature control" method ensures a constant temperature (in this case $130^{\circ} \mathrm{C}$ ) and varying the magnetron power. This method takes place in three stages. In the first step the temperature is raised as quickly as possible (within less than $1 \mathrm{~min}$ ) by applying the maximum power. In the second step the reaction mixture is kept at a constant temperature with the control of the magnetron power. In the last step the reaction tube is cooled to $55^{\circ} \mathrm{C}$ by stopping the irradiation and blowing the reaction vial with compressed air. Once the heating cycle is completed, the reaction vial is removed from the reactor, and processed as indicated for $\mathrm{TH}$.

The conventional TH setup procedures and characterization of all compounds were previously described in [26].

\section{Results and discussions}

In a previously research work, we presented a thoroughly study concerning the reactions of phenanthrolinium ylides, quinolinium ylides, isoquinolinium ylides and phthalazinium ylides (generated in situ in the presence of triehtylamine (TEA) from the corresponding salts) with ethyl cyanoformate, under conventional TH conditions [26]. Normally, the reactions of these ylides with ethyl cyanoformate occur as a Huisgen $3+2$ cycloaddition reaction $[5,10]$. Interestingly, in the case of phenanthrolinium ylides (generated from the corresponding salts $\mathbf{1}, \mathbf{3}, \mathbf{5}$ ) no cycloaddition reaction took place, only nucleophilic substitution (attack of the cyanide ion in the $\gamma$-position, leading to products $2, \mathbf{4}, \mathbf{6}$ ) and an $\alpha$-oxidation take place simultaneously (Scheme 1) and, in the case of 4,7phenanthroline derivative $\mathbf{5 b}$, a supplementary product $\mathbf{7 b}$ ( $\gamma$-cyan substituted) is obtained. 


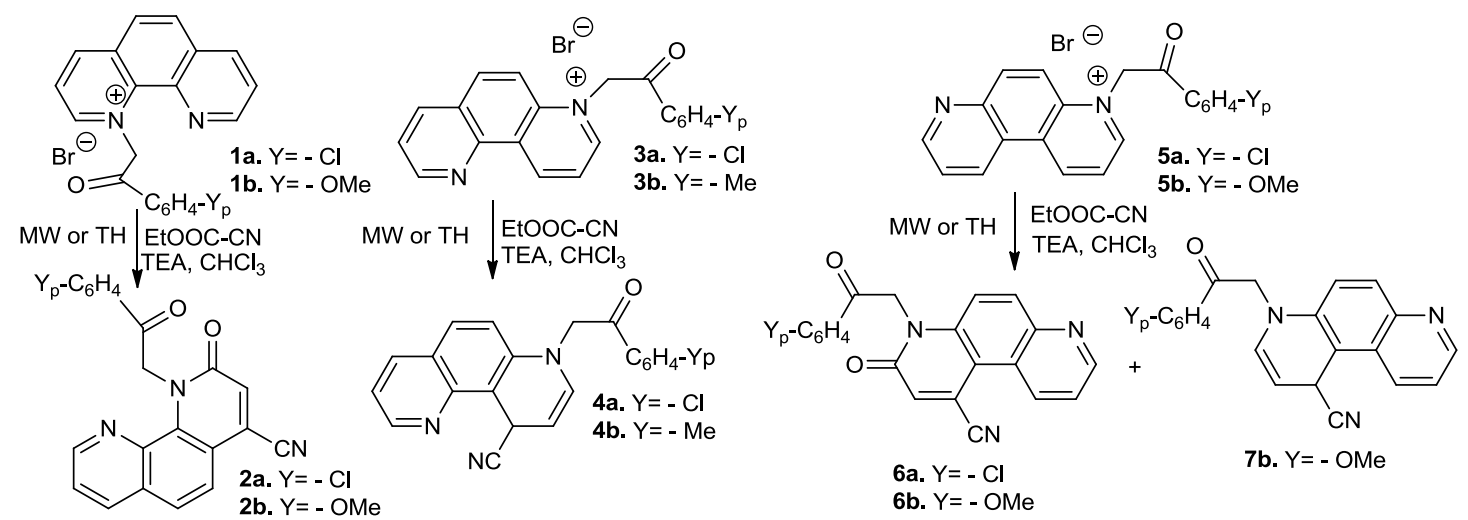

Scheme 1. Reactions of phenanthrolinium ylides with ethyl cyanoformate

In the case of quinolinium ylides, isoquinolinium ylides and phthalazinium ylides (generated from the corresponding salts $\mathbf{8}, \mathbf{1 3}, \mathbf{1 7}$ ), the reactions occur differently (Scheme 2). Thus, in the case of quinolinium derivatives, a nucleophilic substitution (at the $\gamma$-position) and an $\alpha$-oxidation took place simultaneously on the azine ring (leading to products 9), together with some complex chain transformation (leading to the byproducts $10,11,12$ ).

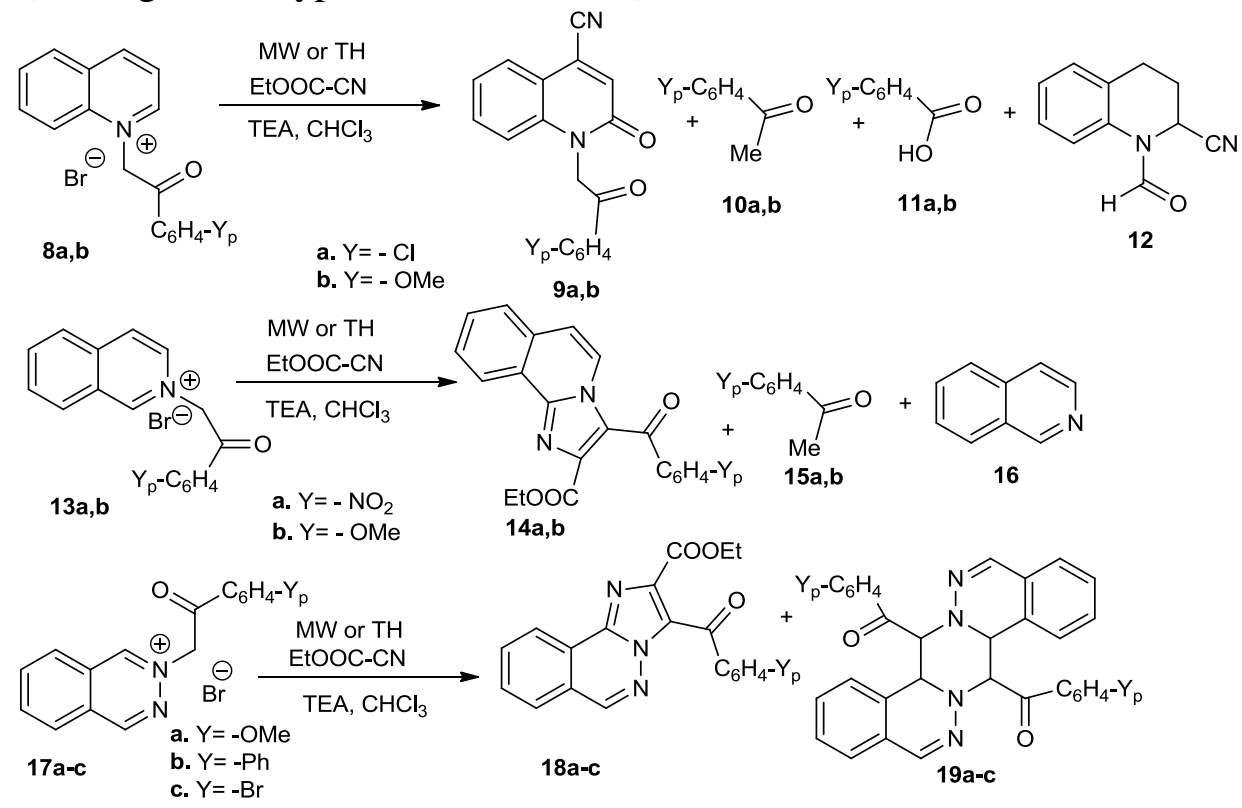

Scheme 2. Reactions of quinolinium ylides, isoquinolinium ylides and phthalazinium ylides with ethyl cyanoformate

In the case of isoquinoline derivatives, the desired $3+2$ cycloaddition reaction took place (leading to the fused imidazo-derivatives 14), together with some complex chain transformation (leading to small amounts of products $\mathbf{1 5}$ and 16). In the case of phthalazinium derivatives, again the $3+2$ cycloaddition reaction took place (leading to the fused imidazo-derivatives 18), together with another concurrent $3+3$ cycloaddition (leading to the dimeric structures 19 ).

From the data presented above, we may noticed that under conventional TH these reactions have some major disadvantages: moderate to low selectivity, side reactions, long reaction time (24 hours), moderate to low yields (around 50\%), etc.

As an alternative route of this synthetic approach, we decide to study the reaction of these six member ring azaheterocycles with ethyl cyanoformate under MW irradiation, using a monomode reactor Monowave 300 (Anton Paar, Graz, Austria). This reactor is equipped with a stirring system (0 
to $1200 \mathrm{rpm}$ ) and can reach up to $300^{\circ} \mathrm{C}$, with temperature control. The reactions take place in a closed vessel, at 30 bars maximum pressure. The optimal reaction conditions were found to be at $130^{\circ} \mathrm{C}, 5.5-$ 6.0 bars, (Table 1). Table 1 lists the optimized reaction conditions we employed under MW irradiation and conventional $\mathrm{TH}$.

Table 1. The synthesis of azaindolizine derivatives under MW irradiation and conventional TH

\begin{tabular}{|c|c|c|c|c|c|c|c|c|c|c|c|c|c|c|c|c|c|c|}
\hline \multicolumn{2}{|c|}{ Compound } & $2 \mathbf{a}$ & $2 \mathrm{~b}$ & $4 a$ & $4 \mathrm{~b}$ & $6 a$ & $6 \mathrm{~b}$ & $7 \mathrm{~b}$ & $9 a$ & $9 \mathrm{~b}$ & $14 a$ & $14 b$ & $18 \mathbf{a}$ & $18 b$ & $18 \mathrm{c}$ & $19 a$ & $19 \mathrm{~b}$ & $19 \mathrm{c}$ \\
\hline MW & $\begin{array}{c}\text { Reaction } \\
\text { time }\end{array}$ & \multicolumn{17}{|c|}{10 minutes } \\
\hline & Yield, \% & 50 & 50 & 60 & 40 & 40 & 75 & 0 & 50 & 40 & 67 & 75 & 50 & 60 & 55 & 5 & 5 & 5 \\
\hline \multirow[t]{2}{*}{ TH } & $\begin{array}{c}\text { Reaction } \\
\text { time }\end{array}$ & \multicolumn{17}{|c|}{24 hours } \\
\hline & Yield, \% & 45 & 50 & 55 & 40 & 40 & 20 & 52 & 40 & 40 & 40 & 45 & 35 & 37 & 35 & 10 & 10 & 10 \\
\hline
\end{tabular}

The results listed in table 1 show that MW irradiation has some undeniable advantages comparative with $\mathrm{TH}$ in the reaction of our azaheterocycles with ethyl cyanoformate, in terms of reaction time, selectivity of reaction and yields. The main advantage is the decrease of reaction times from 24 hours to 10 minutes. In the case of quinolinium ylides and isoquinolinium ylides under MW irradiation, the reactions became selective, only one product being obtained $(\mathbf{9}, \mathbf{1 4})$ and, the yields are higher. In the case of phthalazinium ylides the yields for imidazo-derivatives $\mathbf{1 8}$ are considerably increased (with 1520\%), while the yields for the dimeric structures 19 slightly decreased (with 5\%). For phenanthrolinium ylides, the reactions under MW irradiation occurred almost similarly with the ones under conventional TH (only a slightly increasing of yields being observed), excepting the reaction of salt $\mathbf{5 b}$ that lead in this case to the formation of only compound $\mathbf{6 b}$. That proves the better selectivity of this reaction under MW. The decreasing of reaction times from hours to minutes corroborated with the fact that in majority of cases the yields are higher and the selectivity is better, allow us to say that these reactions could be considered as eco-friendly.

In the final step, we investigated the biological activity, anticancer and antimycobacterial, of some of the new obtained compounds. In order to test the anticancer activity of compounds, we submitted all the synthesized compounds on the platform of National Cancer Institute, US (NCI) for the preliminary selection in order to test them on their 60 human tumor cell line panel. Seven compounds $(\mathbf{2 b}, \mathbf{4 a}, \mathbf{6 b}$, 14a, 18a, 18b, 18c) have been selected and tested for the anticancer activity by NCI, under the Developmental Therapeutics Program (DTP), at a single high dose $\left(10^{-5} \mathrm{M}\right)$ cell assay. This assay was performed in a 60 human tumor cell line panel, representing leukemia, melanoma and cancers of lung, colon, brain, breast, ovary, kidney and prostate, in accordance with the protocol of the NCI [32-35]. The results are expressed as percentage of growth inhibition (PGI) values, and represent growth relative to the no-drug control and relative to the time zero number of cells. This allows detection of both growth inhibition (values between 0 and 100) and lethality (values less than 0 ). Table 2 lists a selection of the obtained results.

Table 2. Percentage growth inhibition (PGI, $\mu \mathrm{M}$ ) of compounds $2 \mathbf{b}, \mathbf{4 a}, \mathbf{6 b}, \mathbf{1 4 a}, \mathbf{1 8 a}, \mathbf{1 8 b}, \mathbf{1 8 c}$ and phenstatin against NCI 60 human tumor cell lines (selection)

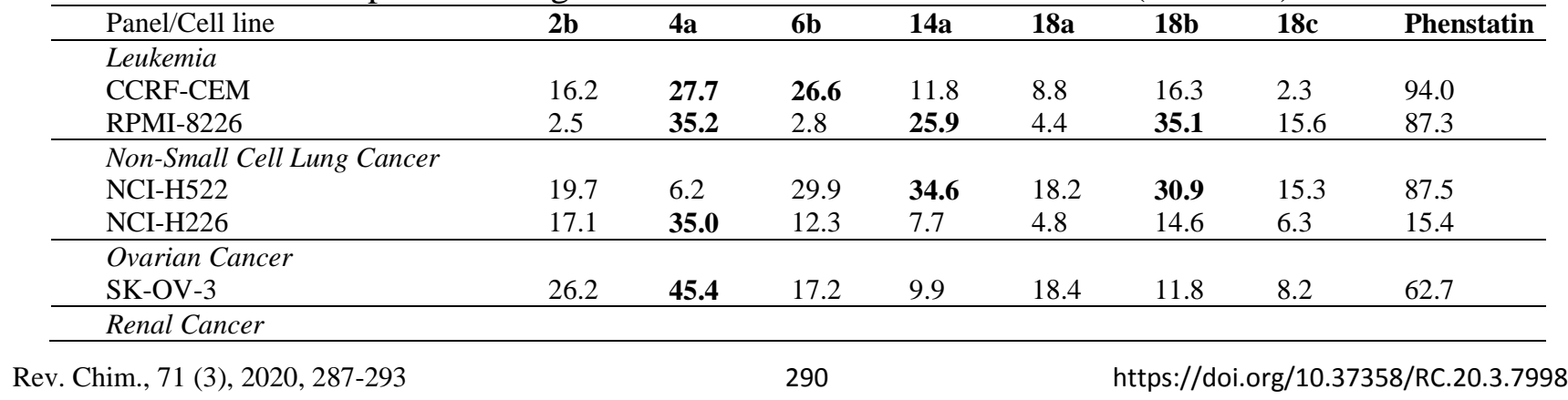




\begin{tabular}{|c|c|c|c|c|c|c|c|c|}
\hline A498 & 17.6 & 46.0 & 12.5 & 31.5 & 20.1 & 0 & 0 & 25.0 \\
\hline UO-31 & 13.0 & 35.8 & 11.8 & 16.1 & 20.6 & 40.3 & 15.7 & 62.3 \\
\hline $\begin{array}{l}\text { Prostate Cancer } \\
\text { PC-3 }\end{array}$ & 15.5 & 39.2 & 20.0 & 31.1 & 9.1 & 38.2 & 15.5 & 79.6 \\
\hline $\begin{array}{l}\text { Breast cancer } \\
\text { MCF7 } \\
\text { MDA-MB-231/ATCC } \\
\text { T-47D }\end{array}$ & $\begin{array}{l}5.4 \\
9.3 \\
10.3\end{array}$ & $\begin{array}{l}22.0 \\
\mathbf{2 8 . 4} \\
18.9\end{array}$ & $\begin{array}{l}6.3 \\
9.0 \\
2.1\end{array}$ & $\begin{array}{l}3.3 \\
16.5 \\
19.8\end{array}$ & $\begin{array}{l}19.2 \\
18.3 \\
14.1\end{array}$ & $\begin{array}{l}17.9 \\
\mathbf{2 9 . 6} \\
\mathbf{4 0 . 7}\end{array}$ & $\begin{array}{l}19.3 \\
1.5 \\
0.3\end{array}$ & $\begin{array}{l}93.8 \\
75.2 \\
45.3\end{array}$ \\
\hline
\end{tabular}

As table 2 shows, derivatives $\mathbf{4 a}, \mathbf{1 4 a}$ and $\mathbf{1 8 b}$ exhibit a significant antitumor growth inhibitory activity against several cell lines. Thus, compound $\mathbf{4 a}$ showed the best growth inhibition properties in the series, with the best values of PGI (around 45\%) against renal cancer A498 and ovarian cancer SKOV-3 cells. Also, moderate activity (35-40\%) was observed against leukemia RPMI-8226, lung cancer NCI-H226, renal cancer UO-31, and prostate cancer PC-3 cells. Compound $\mathbf{1 8 b}$ exhibited a good activity against several tumor cells with the best values of PGI ( 40\%) against renal cancer UO-31, breast cancer T-47D and prostate cancer PC-3 cells, while compound $\mathbf{1 4 a}$ revealed moderate inhibitory activity (31-35\%) against lung cancer NCI-H522, renal cancer A498 and prostate cancer PC-3 cells. Compounds $4 \mathbf{a}$ and $\mathbf{1 4 a}$ showed better growth percentage values against non-Small Cell Lung Cancer NCI-H226 line than Phenstatin used as positive control drug. Compound $4 \mathbf{e}$ showed also a better growth inhibition values against non-Small Cell Lung Cancer NCI-H226 line while compound 18b showed comparative results with Phenstatin.

Compounds $\mathbf{2 b}, \mathbf{6 b}, \mathbf{1 8 a}$ and $\mathbf{1 8 c}$ exhibited only weak insignificant inhibitory properties on some other tumor cells. From the obtained results, we can deduce that the presence of $p$-chlorobenzoyl moieties has a beneficial contribution to the anticancer activity. This finding is in agreement to some previous results obtained in our group that show a good inhibitory activity of compounds containing this structural feature [36-38].

Compounds 2b, 4a, 6b, 14a, 18a, 18b and 18c were also evaluated for the antimycobacterial properties, the testing in primary cycle high throughput screening (determination of the $90 \%$ inhibitory concentration $\left(\mathrm{IC}_{90}\right)$, 50\% inhibitory concentration $\left(\mathrm{IC}_{50}\right)$ and minimum inhibitory concentration (MIC) [39-42] showing that the tested compounds do not present any antimycobacterial activity against M. tuberculosis $H 37 R v$ under aerobic conditions up to concentration of $200 \mu \mathrm{M}$.

\section{Conclusions}

In conclusion, we report herein a comparative study concerning the influence of MW irradiation comparative with conventional $\mathrm{TH}$ in the reaction of six member ring azaheterocycles (derived from phenanthroline, quinoline, isoquinoline and phthalazine) with ethyl cyanoformate, and their anticancer and antimycobacterial activity. Under MW irradiation the reactions have some significant advantages. As a general rule, the reaction times under MW decreased dramatically (from hours to minutes) and the yields of the main products are higher. In the case of 4,7-phenanthrolinium ylides and phthalazinium ylides under MW irradiation, the reactions became more selective. Thus, only one product has been obtained in case of 4,7-phenanthrolinium salt $\mathbf{5 b}$, while in case of phthalazinium salts 17a-c, the yields for the dimeric structures 19 decreased. The decreasing of reaction times from hours to minutes corroborated with the fact that in majority of cases the yield are higher and the selectivity is better, allow us to say that these reactions could be considered as eco-friendly. Seven compounds were evaluated by NCI for the anticancer properties, three of them possessing promising activity against several cancer cell lines including leukemia, non-small cell lung cancer, ovarian cancer, renal cancer and breast cancer. The best activity was those one of compound $\mathbf{4 a}$ which possess a p-chlorobenzoyl moiety, with indicate a clearly beneficial contribution to the anticancer activity. Other two compounds, $\mathbf{1 8 a}$ and $\mathbf{1 8 b}$, showing also good inhibitory properties, have as common structural feature the presence of a fused substituted imidazole, which indicate also a positive contribution of this moiety to the enhancing of anticancer activity. Seven compounds were also tested for antimycobacterial activity against Mycobacterium tuberculosis but none of them showed measurable activity. 
Acknowledgments: Authors are thankful to Romanian Ministry of Research and Innovation, Program 1- Development of the national R \& D system, Subprogram 1.2 - Institutional performance - RDI excellence financing projects, Grant no. 34PFE/19.10.2018 and UEFISCDI Bucharest, Romania, project PN-III-P1-1.1-TE-2016-1205 for financial support and the POSCCE-O 2.2.1, SMIS-CSNR 13984-901, No. 257/28.09.2010 Project, CERNESIM, for NMR experiments.

\section{References}

1.DABROWSKA, S., CHUDOBA, T., WOJNAROWICZ, J., ŁOJKOWSKI, W., Crystals, 8, 2018, p. 379.

2.HORIKOSHI, S., SCHIFFMANN, R.F., FUKUSHIMA, J., SERPONE, N., Microwave Chemical and Materials Processing, 1st ed., Springer: Singapore, 2018.

3.CRAVOTTO, G., CARNAROGLIO, D., (Eds.) Microwave Chemistry, De Gruyter: Berlin/Boston, 2017.

4.LOUPY, A. (Ed.) Microwaves in Organic Synthesis, 2nd ed., Wiley-VCH: Weinheim, 2006.

5.VAN DER EYCKEN, E., KAPPE, C.O. (Eds.) Microwave-Assisted Synthesis of Heterocycle, Springer-Verlag: Berlin, Heidelberg, 2006.

6.KAPPE, O.C., STADLER, A. (Eds.) Microwaves in Organic and Medicinal Chemistry; Wiley-VCH: Weinheim, Germany, 2005.

7.MOLDOVEANU, C., MANGALAGIU, I.I., ISAC, D.L., AIRINEI, A., ZBANCIOC, G., Molecules, 23, 2018, p. 1968.

8.MULLER, T., DANAC, R., BALL, L., GURR, S.J., FAIRBANKS, A.J., Tetrahedron Asymmetry, 18, 2007, p. 1299.

9.ZBANCIOC, G., MOLDOVEANU, C., ZBANCIOC, A.M., MANGAlAGIU, I.I., Curr. Microw. Chem., 1, 2014, p. 41.

10.ZBANCIOC, G., ZBANCIOC, A.M., MANGALAGIU, I.I., Ultrason. Sonochem., 21, 2014, p. 802. 11.RADULY, M.F., RADITOIU, V., RADITOIU, A., WAGNER, L.E., AMARIUTEI, V., AILIESEI DARVARU, G., Rev. Chim., 69, (6), 2018, 1327.

12.ZBANCIOC, A.M., MIRON, A., MOLDOVEANU, C., ZBANCIOC, G., Rev. Chim., 64, (6), 2013, 584.

13.BALAN, A.M., ZBANCIOC, G., BENTEA, E., CARJA, I., UNGUREANU, M., TUCHILUS, C., MANGALAGIU, I.I., Rev. Chim., 60, (10), 2009, 1021.

14.KAPPE, O.C., Angew. Chem. Int. Ed., 43, 2004, p. 6250.

15.LIDSTRÖM, P., TIERNEY, J., WATHEY, B., WESTMAN, J., Tetrahedron, 57, 2001, p. 9225.

16.ZHANG, J., WANG, S, BA, Y, XU, Z., Eur. J. Med. Chem., 174, 2019, p. 1.

17.OLARU, A.M., VASILACHE, V., DANAC, R., MANGALAGIU, I.I., J. Enz. Inhib. Med. Chem., 32, 2017, p. 1291.

18.MANTU, D, ANTOCI, V, NICOLESCU, A, DELENU, C., VASIlACHE, V., MANGALAGIU, I.I., Curr. Org. Synth., 14, 2017, p. 112.

19.MANTU, D., LUCA, M.C., MOLDOVEANU, C., ZBANCIOC, G., MANGALAGIU, I.I., Eur. J. Med. Chem., 45, 2010, p. 5164.

20.MANTU, D., ANTOCI, V., MANGALAGIU, I.I., Infect. Disord. Drug. Targets, 13, 2013, p. 344.

21.MANTU, D., ANTOCI, V., MOLDOVEANU, C., ZBANCIOC, G., MANGALAGIU, I.I., J. Enz. Inhib. Med. Chem., 31, 2016, p. 96.

22.POPOVICI, L., AMARANDI, R.M., MANGALAGIU I.I., MANGALAGIU, V., DANAC, R., J. Enz. Inhib. Med. Chem., 34, 2019, p. 230.

23.BELlET, V., LICHON, L., ARAMA, D.P., GALlUD, A., LISOWSKI, V., MAILlARD, L.T., GARCIA, M., MARTINEZ, J., MASURIER, N., Eur. J. Med. Chem., 125, 2017, p. 1225.

24.MANTU, D., MAFTEI, D., IUREA, D., URSU, C., BEJAN, V., Med. Chem. Res., 23, 2014, p. 2909.

25.KALARIA P.N., KARAD S.C., RAVAL D.K.A., Eur. J. Med. Chem., 158, 2018, p. 917. 
26.AL MATARNEH, C.M., APOSTU, M.O., MANGALAGIU I.I., DANAC, R., Tetrahedron, 72, 2016, p. 4230.

27.ROTARU, A., DANAC, R., DRUTA, I., DROCHIOIU, G., CRETESCU, I., Rev. Chim. , 56, 2005, 179.

28.GRADINARU, R., LUCA, A., CRETESCU, I., DANAC, R., Rev. Chim., 61, 2010, 903.

29.ZBANCIOC, G., HUHN, T., GROTH, U., DELEANU, C., MANGALAGIU, I.I., Tetrahedron, 66, 2010, p. 4298.

30.DANAC, R., BALL, L., GURR, S.J., MULLER, T., FAIRBANKS, A.J., ChemBioChem., 8, 2007, p. 1241.

31.PRICOPE, G., URSU, E.L., SARDARU, M., COJOCARU, C., ClIMA, L., MARANGOCI, N., DANAC, R., MANGAlAGIU, I., SIMIONESCU, B.C., PINTEALA, M., ROTARU, A., Polym. Chem., 9, 2018, p. 968.

32.***, US National Cancer Institute (NCI), Bethesda, http://dtp.nci.nih.gov/

33.SHOEMAKER, R.H., Nat. Rev., 6, 2006, p. 813.

34.MONKS, A., SCUDIERO, D., SKEHAN, P., SHOEMAKER, R., PAULL, K., VISTICA, D., HOSE, C., LANGLEY, J., CRONISE, P., VAIGRO-WOLFE, A., GRAY-GOODRICH, M., CAMPBELL, H., BOYD, M.R., J. Natl. Cancer Inst., 83, 1991, p. 757.

35.BOYD, R.M., PAULL, K.D., Drug Develop. Res., 34, 1995, p. 91.

36.DANAC, R., AL MATARNEH, C.M., SHOVA, S., DANILOAIA, T., BALAN, M., MANGALAGIU, I.I., Bioorg. Med. Chem., 23, 2015, p. 2318.

37.AL MATARNEH, C.M., ShOVA, S., MANGALAGIU, I.I., DANAC, R., J. Enz. Inhib. Med. Chem., 31, 2016, p. 470.

38.AL MATARNEH, C.M., CIOBANU, C.I., MANGALAGIU, I.I., DANAC, R., J. Serb. Chem. Soc., 81, 2016, p. 133.

39.OllingER, J., BAILEY, M.A., MORASKI, G.C., CASEY, A., FlORIO, S., Alling, T., MILLER, M.J., PARISH, T., PLoS One, 8, 2013, p. 60531.

40.ZELMER, A., CARROLl, P., ANDREU, N., HAGENS, K., MAHLO, J., REDINGER, N., ROBERTSON, B.D., WILES, S., WARD, T.H., PARISH, T., RIPOLL, J., BANCROFT, G.J., SCHAIBLE, U.E., J. Antimicrob. Chemother., 67, 2012, p. 1948.

41.CARROLL, P., SCHREUDER, L.J., MUWANGUZI-KARUGABA, J., WILES, S., ROBERTSON, B.D., RIPOLL, J., WARD, T.H., BANCROFT, G.J., SCHAIBLE, U.E., PARISH, T., PLoS One, 5, 2010, p. 9823.

42.LAMBERT, R.J., PEARSON, J., J. Appl. Microbiol., 88, 2000, p. 784.

$\overline{\text { Manuscript received: } 24.03 .2020}$ 